\title{
Thyroid Gland Hurthle Cell Adenoma
}

National Cancer Institute

\section{Source}

National Cancer Institute. Thyroid Gland Hurthle Cell Adenoma. NCI Thesaurus. Code C6042.

A thyroid gland adenoma composed of large cells with abundant granular eosinophilic cytoplasm and large nuclei with prominent nucleoli. 